\title{
Coupling of Vegetation Growing Season Anomalies and Fire Activity with Hemispheric and Regional-Scale Climate Patterns in Central and East Siberia
}

\author{
Heiko Balzter,* France Gerard, ${ }^{+}$Charles George, ${ }^{+}$Graham Weedon, \# Will Grey, ${ }^{\#}$ Bruno \\ Combal, ${ }^{@}$ Etienne Bartholomé, ${ }^{@}$ Sergey Bartalev, \& and Sietse Los ${ }^{\#}$ \\ *Climate and Land Surface Systems Interaction Centre, Department of Geography, University of Leicester, Leicester, \\ United Kingdom \\ $+{ }^{+}$Climate and Land Surface Systems Interaction Centre, Centre for Ecology and Hydrology, Section for Earth Observation, \\ Huntingdon, United Kingdom \\ \# Climate and Land Surface Systems Interaction Centre, Department of Geography, University of Swansea, Swansea, United Kingdom \\ @ Joint Research Centre of the European Commission, Institute for Environment and Sustainability, Global Environment \\ Monitoring Unit, Ispra, Italy \\ \& Boreal Ecosystems Monitoring Laboratory, Space Research Institute, Russian Academy of Sciences, Moscow, Russia
}

(Manuscript received 23 February 2006, in final form 5 December 2006)

\begin{abstract}
An 18-yr time series of the fraction of absorbed photosynthetically active radiation (fAPAR) taken in by the green parts of vegetation data from the NOAA Advanced Very High Resolution Radiometer (AVHRR) instrument series was analyzed for interannual variations in the start, peak, end, and length of the season of vegetation photosynthetic activity in central and east Siberia. Variations in these indicators of seasonality can give important information on interactions between the biosphere and atmosphere. A second-order local moving window regression model called the "camelback method" was developed to determine the dates of phenological events at subcontinental scale. The algorithm was validated by comparing the estimated dates to phenological field observations. Using spatial correlations with temperature and precipitation data and climatic oscillation indices, two geographically distinct mechanisms in the system of climatic controls of the biosphere in Siberia are postulated: central Siberia is controlled by an "Arctic Oscillation-temperature mechanism," while east Siberia is controlled by an "El Niño-precipitation mechanism." While the analysis of data from 1982 to 1991 indicates a slight increase in the length of the growing season for some land-cover types due to an earlier beginning of the growing season, the overall trend from 1982 to 1999 is toward a slightly shorter season for some land-cover types caused by an earlier end of season. The Arctic Oscillation tended toward a more positive phase in the 1980s leading to enhanced high pressure system prevalence but toward a less positive phase in the 1990s. The results suggest that the two mechanisms also control the fire regimes in central and east Siberia. Several extreme fire years in central Siberia were associated with a highly positive Arctic Oscillation phase, while several years with high fire damage in east Siberia occurred in El Niño years. An analysis of remote sensing data of forest fire partially supports this hypothesis.
\end{abstract}

\section{Introduction}

\section{a. Goal of this study}

Northern Eurasia is particularly vulnerable to climate change because its ecosystems are largely temperature controlled and the largest increases in temperatures are predicted to occur in high latitudes; these increases can be double the temperature increases in

Corresponding author address: Heiko Balzter, Climate and Land Surface Systems Interaction Centre, Department of Geography, University of Leicester, University Road, Leicester, LE1 7RH, United Kingdom.

E-mail: hb91@le.ac.uk

DOI: $10.1175 /$ JCLI4226 the Tropics. Consequences of the expected warming trend include shifts in the seasonality of the growing season (vegetation phenology) and potentially an increase in fire frequency and damage. This study aims to undertake an identification of potential coupling mechanisms between large-scale climate patterns (e.g., Arctic Oscillation, El Niño), vegetation phenology, and fire over central and eastern Siberia using a combined analysis of satellite and climate data.

\section{b. Background}

The boreal forest covers approximately 1.37 billion ha, or $9.2 \%$ of the world's land surface (Roy et al. 2001) 


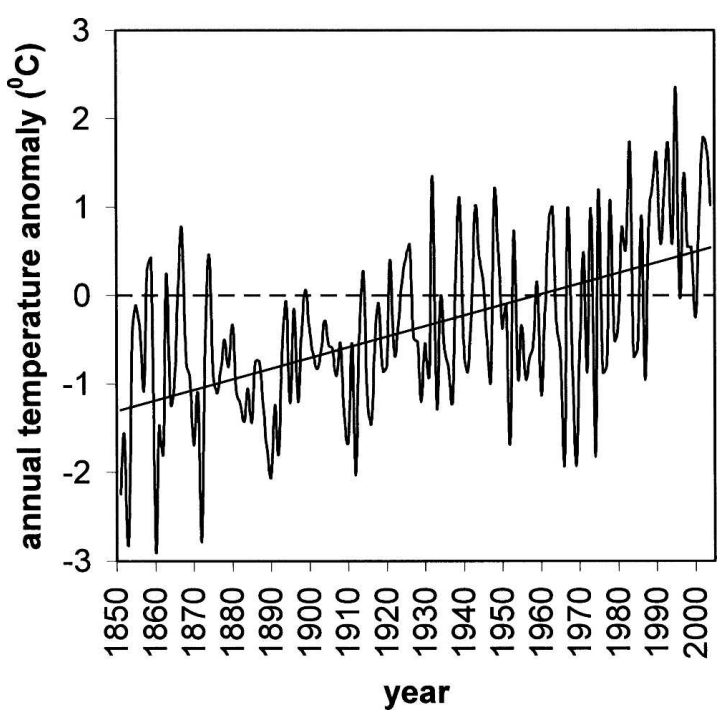

FIG. 1. Annual temperature anomaly data $\left({ }^{\circ} \mathrm{C}\right)$ from CRUTEM2 dataset from 1851 to 2004 for central Siberia $\left(50^{\circ}-\right.$ $\left.70^{\circ} \mathrm{N}, 80^{\circ}-120^{\circ} \mathrm{E}\right)$, and linear trend line $(y=0.012 \times-23.476)$. After 1990 there is a tendency toward more frequent positive residuals, indicating a higher temperature increase than expected from the linear trend.

in a circumpolar complex of forested and partially forested ecosystems in northern Eurasia and North America. Under global warming scenarios coupled biome-climate models predict a significant reduction of the extent of tundra and a northward expansion of the boreal forest in Eurasia (Harding et al. 2002). Annual temperature anomalies since 1850 over central Siberia show a trend toward warmer temperature anomalies (Fig. 1). The residuals of the observed temperature anomalies from the linear trend fitted over the time series show warmer conditions than expected from the linear trend after 1990 (Fig. 1). The lower troposphere of eastern Siberia to northern Canada also showed relatively warm spring temperatures in the 1990s (Overland et al. 2002), with four particularly warm springs in the 1990s and four cold springs in the 1980s. The observed shift in wind fields from anomalous northeasterly flow in the 1980s to anomalous southwesterly flow in the 1990s during March and April in that region coincided with a systematic shift in the Arctic Oscillation (AO) near the end of the 1980s (Overland et al. 2002). Surface air temperature and precipitation data from 1958 to 1999 from 10 meteorological stations in west Siberia were analyzed by Frey and Smith (2003). Their findings show that west Siberia is warming and shows increases in precipitation (most notably springtime warming and winter precipitation increases), and the association of particularly autumn and winter temperatures with the $\mathrm{AO}$. On average, the AO was linearly correlated with
96\% (winter), 19\% (spring), 0\% (summer), 67\% (autumn), and 53\% (annual) of the warming (Frey and Smith 2003). These observed temperature trends coincide with changes in solar radiation intensity recorded at the land surface. An analysis of incident solar radiation measured at 160 actinometric stations in the former Soviet Union showed a decreasing tendency in the time series of direct and global solar radiation between 1958 and 1993 , with $60 \%$ of station records showing a statistically significant decrease (Abakumova et al. 1996). This decline in solar radiation has become apparent in other observational records, too, up to about 1990. However, more recent surface observations from 1990 to the present, primarily from the Northern Hemisphere, show that this decline did not persist into the 1990s but has reversed to an increase since the late 1980s (Wild et al. 2005). This was unexpected, given the vast amounts of volcanic aerosols emitted during the Pinatubo eruption in 1991. Whether this reversal of this "global dimming" effect is associated with the recent temperature increases in Siberia is unclear.

Research has shown that over the period 1980-95, year-to-year differences in the carbon flux from terrestrial metabolism have almost been as large as variations in the growth rate of atmospheric $\mathrm{CO}_{2}$ (Houghton 2000). Depending on the dominant processes, biosphere feedbacks to the climate system can accelerate or slow down climate change (Cox et al. 2000). Fluxes of heat, water, carbon, and other greenhouse gases between the land surface and the atmosphere interact in complex nonlinear ways (Delworth and Manabe 1993; Koster et al. 2000). The availability of long-term datasets of the state of the land surface-and particularly the biosphere-from satellite records creates new opportunities for quantifying land surface-atmosphere interactions.

Phenology investigates trends in the timing of recurrent seasonal events. A statistical framework for the analysis of Advanced Very High Resolution Radiometer (AVHRR) time series data is presented by de Beurs and Henebry (2005). The same authors relate changes in normalized difference vegetation index (NDVI) to annual growing degree days. However, in their Kazakhstan study, de Beurs and Henebry (2005) find that significant changes in phenology were only detected for some land-cover types but not for others. For the Amazon Basin, Asner et al. (2000) find that the seasonal NDVI amplitude in the AVHRR time series from 1982 to 1993 increased during El Niño periods with low rainfall anomalies and decreased during wet La Niña episodes. Stockli and Vidale (2004) analyze AVHRR data from 1982 to 2001 and find that European spring phenology correlates with anomalies in 
winter temperature and winter North Atlantic Oscillation (NAO) index. In a study of remotely sensed leaf appearance dates in central Siberia, Vicente-Serrano et al. (2006) find a strong correlation with sea surface temperatures over the equatorial Pacific of the previous summer, related to El Niño-Southern Oscillation patterns. Delbart et al. (2005) study the dates of the onset of green up and leaf senescence over central Siberia using the same phenology field data as in the current study together with three different spectral indices from the SPOT-VEGETATION sensor. They conclude that in the boreal biome NDVI-based greening-up dates are affected strongly by snow effects influencing the spectral signatures at the red and near-infrared bands. In contrast to NDVI, the normalized difference water index (NDWI) only shows a small snow effect. The estimated dates of leaf coloring in autumn show a lesser accuracy than the greening-up dates (Delbart et al. 2005). Using the same SPOT-VEGETATION data and the AVHRR data record, Delbart et al. report an average advance of spring green up over Siberia of 3.5 days between 1982 and 2004. This trend varies spatially across regions and temporally. From 1982 to 1991 the start of the green up advanced by 7.8 days, but between 1991 and 1999 only random variation is observed, and from 2000 to 2004 a trend toward a later greening up by as much as 7 days is apparent (Delbart et al. 2006). Satellite-derived phenology data offer spatial and temporal information but are not always consistent with field observations. Badeck et al. (2004) conclude that, while there is a qualitatively consistent advancement of vegetation activity in spring using ground observations, remote sensing, and the atmospheric $\mathrm{CO}_{2}$ signal, the trends for spring advancement differ substantially between the different methods.

Analyzing NDVI data from 1981 to 1991 Myneni et al. (1997) observed a greening trend and an increase in growing season length in the Northern Hemisphere that they attributed to a biosphere response to climate change (predominantly temperature). Lucht et al. (2002) modeled this greening trend using a biogeochemical vegetation model and observed climate data. They found a setback in the greening trend after the Pinatubo eruption in 1991, an effect of the temporary cooling caused by the eruption. Subsequently, Slayback et al. (2003) showed that after the Pinatubo eruption in June 1991 a drop in NDVI was observed that was probably caused by reduced vegetation photosynthetic activity because of a dimming and cooling effect from volcanic aerosols. Nemani et al. (2003) showed decreased net primary productivity over Siberia over the same time period. The drop in NDVI reported by Slayback et al. (2003) was greater at higher latitudes, and particularly pronounced in the boreal zone in Canada and Siberia. It was so strong that Slayback et al. calculated NDVI trends for these regions over the 1982-99 period to be almost zero, despite the evidence for a Northern Hemisphere greening trend observed by Bogaert et al. (2002) using averaged NDVI values over the growing season. Gong and Ho (2003) analyzed the Pathfinder spring NDVI-temperature relationship over Eurasia and North America for 1982-2000 and found that rapid warming has resulted in an early growing season. The differences in remote sensing data processing methods and statistical analysis tools make direct comparisons between the aforementioned studies difficult.

Atmospheric oscillations have an impact on regional climatic variability and consequently vegetation activity. Los et al. (2001) and Buermann et al. (2003) found that two predominant hemispheric-scale modes of covariability are related to teleconnections associated with the ENSO and AO: While the warm event ENSO signal is associated with warmer and greener conditions in far East Asia, the positive phase AO leads to enhanced warm and green conditions over large regions in Asian Russia. However, Los et al. (2001) found a negative relationship between temperature and vegetation greenness at the time scales of variability of the NAO, a regional index related to the hemispheric variability in the AO, and ENSO for the Russian part of Asia during the 1980s.

In the recent past Siberia has experienced extreme fire years (Sukhinin et al. 2004), which coincided with years in which the AO was in a more positive phase (Balzter et al. 2005). Jupp et al. (2006) found that regional clusters of fire scars in Siberia occurred in places with dry precipitation anomalies at scales of tens of kilometers. Fires release carbon and aerosols into the atmosphere and can alter the carbon balance (Kasischke et al. 2005).

The seasonal vegetation cycle is determined by temperature and moisture conditions and other factors (e.g., soil, plant species). Through the hydrological processes controlling evapotranspiration, temperature and moisture also influence the combustibility of the organic soil and litter layer and the forest understory. Because the seasonality of the greening up and senescence of plants is controlled by similar ecological processes as the forest fire regime, the two processes are interlinked. Forest fires play an important role in global atmospheric chemistry. Aerosol emissions from ground-based air samples at three Pinus sylvestris (L.) forest sites in central Siberia that were burned in an experiment ranged from 0.1 to $0.7 \mathrm{tha}^{-1}$ or $1 \%-7 \%$ of the total biomass (10-30 $\mathrm{t} \mathrm{ha}^{-1}$ ) consumed during the 
experimental fires (Samsonov et al. 2005). Anomalies in atmospheric trace gas concentrations from the Commonwealth Scientific and Industrial Research Organisation's (CSIRO) global sampling network in 1994/95 and 1997/98 are consistent with gas emission pulses from extreme fires in the Tropics and the boreal biome (Langenfelds et al. 2002). For the 1997/98 burning carbon dioxide anomalies it is thought that $66 \%$ of the growth rate anomaly can be attributed to global biomass burning, of which $10 \%$ originated from the global boreal biome (van der Werf et al. 2004). During the summer of 2003, forest fires in Siberia reached extreme levels. The smoke plumes were transported via atmospheric pathways from Siberia to North America, which was confirmed by atmospheric modeling and aircraft and ground observations (Jaffe et al. 2004). The carbon monoxide emissions from forest and peat land fires in Russia are consistent with anomalous atmospheric measurements observed in Alaska. Mattis et al. (2003) observed distinct aerosol layers in May and early June 2003 just above the atmospheric boundary layer (3-7 $\mathrm{km}$ ), and a vertically homogeneous aerosol distribution that reached the tropopause at the end of June and in July. They suggest that the severe forest fires in Siberia in spring 2003 are the most plausible cause for these observed tropospheric dynamics. Backward dispersion modeling indicated that intense forest fires that occurred in Siberia and Canada in spring and summer 2003 were the main cause of the tropospheric haze layers (Muller et al. 2005). Atmospheric transport of pyrogenic aerosols over intercontinental distances can be enhanced during El Niño events owing to the changed meteorological conditions over the Pacific, as was observed for aerosol pathways from Siberia to Canada in 1998 by Spichtinger et al. (2004).

For 1998 - another catastrophic fire year in RussiaKasischke and Bruhwiler (2003) have estimated that around 17.9 million hectares of land burned in the global boreal forest region. Conard et al. (2002) estimate that fires in the Russian boreal forest in 1998 contributed $14 \%-20 \%$ to the annual global carbon emissions from forest fires. As a result of a combination of human negligence, land use, and climate change the Siberian fire regime is expected to accelerate. Kharuk et al. (2005) study the periodicity of larch forest fires in Evenkia Oblast, Siberia, and found that on decadal time scales the number of fires regularly peaks at periods of 36 and $82 \mathrm{yr}$. Between the twentieth and twentyfirst centuries the mean fire return interval in Evenkia reduced from approximately $100 \mathrm{yr}$ to about $65 \mathrm{yr}$ (Kharuk et al. 2005).

Here we analyze 18 years of the fraction of absorbed photosynthetically active radiation (fAPAR) data from
1982 to 1999 derived from the NOAA AVHRR over eastern Eurasia. Indicators of the start, peak, end, and length of the growing season are extracted from the data with a local moving window regression approach. The phenological indicators are then statistically compared to regional-scale temperature and precipitation data as well as large-scale climatic modes of variability such as ENSO and AO to investigate climatic controls of the biospheric seasonality in the region. Seasonal shifts in vegetation activity can potentially have large impacts on biosphere-atmosphere exchange processes of heat, water vapor, and carbon dioxide.

\section{Data and methods}

\section{a. Satellite data}

The fAPAR is a biophysical parameter derived from NDVI data. The AVHRR Fourier-Adjusted Sensor and Solar zenith angle corrected, interpolated, reconstructed (FASIR) data used in the present analysis are derived from Pathfinder red and near-infrared AVHRR land data (PAL: see James and Kalluri 1994) corrected for residual effects of sensor degradation and inaccuracies in vicarious calibration, volcanic aerosols, bidirectional reflectance distribution factor (BRDF) effects, cloud effects in tropical forests, and short-term aerosol and cloud effects ( $\leq$ two months and missing data during winter in boreal forests). The fAPAR data for central and eastern Siberia were on a $0.08^{\circ}$ grid scale with a temporal resolution of 1 dekaday (dad) (a roughly 10-day period from days 1 to 10,11 to 20 , and 21 to the end of the month). (Further information about this dataset can be found at http://islscp2.sesda.com/ ISLSCP2_1/data/vegetation/fasir_biophys_monthly_ $\mathrm{xdeg} /$.

\section{b. The camelback phenology algorithm}

An algorithm was developed to extract the timing of the start, peak, and end of the growing season over boreal Eurasia from phenological remote sensing data such as the AVHRR FASIR fAPAR dataset. Start, peak, end, and length of the growing season were automatically estimated. For each year, anomalies of the phenological indicators are calculated as deviations from their long-term average. The phenological anomalies are compared to a set of climate indicators and gridded climate data, and spatial correlation maps between climate variables and vegetation-season anomalies are presented. The algorithm is based on secondorder derivatives. The method is motivated by earlier work by Moulin et al. (1997). From satellite observations regular estimates of fAPAR are available every 8 , 10 , or 16 days. The mathematical problem of identifying 
time points in this time series that indicate a phenological switch can be formulated such that the time point of the start, peak, and end in the phenological curve have to be determined. This problem was solved as follows. First, a window of 5-dad width is moved over the fAPAR time series for each pixel separately and within the temporal window a linear regression of fAPAR against time is calculated. The slope of this local regression is stored. In a second iteration, the second-order derivative is calculated using the same moving window linear regression. It is used to detect start, peak, and end of the growing season.

The following vegetation phenology indicators were defined: (i) The start of the growing season is the time point when the second derivative of the moving window regression (5 dad wide) reaches a local maximum within a 13-dad window, and the first-order slope is positive (fAPAR is increasing). (ii) The peak of the growing season is the time point when fAPAR reaches a local maximum within a 13-dad window. If consecutive fAPAR values have the same value, the peak is the time when this constant value is first reached. (iii) The end of the growing season is the time point when the second derivative of the moving window regression (5 time points wide) reaches a local maximum within a 13-dad window, and the first-order slope is negative (fAPAR is decreasing). (iv) The length of the green season is the difference between the end and start of the season. Multiple peaks do not occur in the boreal ecosystems studied here.

\section{c. Climate data}

The influences of the following climate variables on the phenological anomalies were examined over a region between $50^{\circ}$ and $75^{\circ} \mathrm{N}, 85^{\circ} \mathrm{E}$ and $180^{\circ}$ (centraleastern Eurasia):

Land air temperature: The University of East Anglia Climate Research Unit (CRU) temperature dataset (CRUTEM2) contains land air temperature anomalies on a $5^{\circ} \times 5^{\circ}$ grid from 1851 to the present (see Jones and Moberg 2003 for details; more information is available online at http://www. cru.uea.ac.uk/ftpdata/crutem2.zip). The data were expanded to $2.5^{\circ}$ spacing for the analysis with the precipitation data.

Land precipitation: A 50-yr monthly precipitation climatology for the global land areas (excluding Greenland and Antarctica) is available from 1951 to 2000 from the Variability Analysis of Surface Climate Observations (VASClimO) project (more information is available online at http://www. dwd.de/en/FundE/Klima/KLIS/int/GPCC/
Projects/VASClimO/VASClimO.htm). The data are gridded at three different resolutions $\left(0.5^{\circ}, 1^{\circ}\right.$, and $2.5^{\circ}$ ) on the basis of quality-controlled station data (Rudolf et al. 1994, 2003). The $2.5^{\circ}$ grid was used here.

Arctic Oscillation index: The AO quantifies opposing atmospheric pressure patterns in the northern middle and high latitudes. The AO is in its negative phase when relatively high pressure systems prevail over the polar region and low pressure systems dominate at midlatitudes $\left(45^{\circ} \mathrm{N}\right)$. Its positive phase shows a reversed pattern. The monthly AO index was obtained from the NOAA/National Weather Service, Climate Prediction Center (more information is available online at http://www. cpc.ncep.noaa.gov/products/precip/CWlink/ daily_ao_index/monthly.ao.index.b50.current. ascii.table).

El Niño indices: Regional monthly El Niño indices were obtained for Niño-1 and $-2\left(0^{\circ}-10^{\circ} \mathrm{S}, 90^{\circ}-\right.$ $\left.80^{\circ} \mathrm{W}\right)$, Niño-3 $\left(5^{\circ} \mathrm{N}-5^{\circ} \mathrm{S}, 150^{\circ}-90^{\circ} \mathrm{W}\right)$, and Niño-4 $\left(5^{\circ} \mathrm{N}-5^{\circ} \mathrm{S}, 160^{\circ} \mathrm{E}-150^{\circ} \mathrm{W}\right)$ regions from the NOAA/National Weather Service, Climate Prediction Center (more information is available online at http://www.cpc.ncep.noaa.gov/data/indices/sstoi. indices).

To enable a grid box aggregation of the phenological anomaly data from AVHRR fAPAR time series data, the image files were cut out for the region between $50^{\circ}$ and $75^{\circ} \mathrm{N}, 85^{\circ} \mathrm{E}$ and $180^{\circ}$ and resampled from about $0.08^{\circ}$ to $0.1^{\circ}$ pixel size using a nearest-neighbor algorithm in the ENVI image processing software. A Pearson correlation coefficient was calculated over all years from 1951 to 2000 for the climate data and from 1982 to 1999 for the AVHRR-derived phenological indicator data. The statistical significance of the correlation coefficient $r$ was tested using a two-sided $t$ test with $n-2$ degrees of freedom: $t=r \sqrt{(n-2) /\left(1-r^{2}\right)}$.

\section{d. Phenology field data}

Ground observations of vegetation phenology from Siberia were provided by V. Fedotova (St. Petersburg) for three locations within the study region: Ilir, Bratski district $\left(53^{\circ} 13^{\prime} 0^{\prime \prime} \mathrm{N}, 100^{\circ} 41^{\prime} 0^{\prime \prime} \mathrm{E}\right)$; Taseevo, Luchki $\left(57^{\circ} 0^{\prime} 11^{\prime \prime} \mathrm{N}, 9^{\circ} 0^{\prime} 50^{\prime \prime} \mathrm{E}\right)$; and Krasnoyarsk $\left(56^{\circ} 0^{\prime} 0^{\prime \prime} \mathrm{N}\right.$, $\left.93^{\circ} 0^{\prime} 0^{\prime \prime} \mathrm{E}\right)$.

\section{e. Land-cover data}

The global land-cover 2000 map (GLC2000) (Bartalev et al. 2003) was used to stratify the area by landcover type for parts of the statistical analysis. The GLC2000 data were filtered with a $9 \times 9$ mode filter 
and then resampled to the same resolution as the fAPAR data, effectively assigning the most frequent land-cover class within each resampling window to the central pixel. The fAPAR images were reprojected from the Interrupted Goode's Homolosine projection to the geographic projection. Within each of the 30 GLC2000 land-cover classes the average start-, peak-, end-, and length-of-season anomalies was calculated for each year. A linear regression of the average anomalies was then calculated against time.

\section{f. Burned area data}

For the analysis of coupling of vegetation seasonality with the fire regime, burned area statistics from different sources were used. Remotely sensed burned forest area statistics of a large region of central Siberia from 1992 to 2003 (Balzter et al. 2005) were used. Observational evidence from the U. N. Environment Program (UNEP) 1998 (http://www.grid.unep.ch/activities/ global_change/russia.php) for east Siberia was also interpreted. Satellite-derived burned area data were published by Sukhinin et al. (2004). Annual burned forest area statistics derived from SPOT-VEGETATION from 2000 to 2004 were available from Bartalev et al. (2007).

\section{Results}

\section{a. Validation of remote sensing indicators with phenology field data}

The camelback algorithm was validated in a pilot study for the time period from 1995 to 1999 using the phenology field data at three locations described in section 2d. Sample fAPAR temporal profiles and derived first-order and second-order slopes for one year, 1995 (i.e., $36 \mathrm{dad}$ ), at a particular pixel location are presented in Fig. 2. Figure 3 shows the average and standard deviation of the Julian days of the available phenological indicators from field observations and remote sensing over the three sites and five years. The remotely sensed start of season falls on average between the snowmelt in the forest and the start of the movement of liquid in Betula pubescens (Ehrh.) and B. pendula (Roth). For the purpose of this study-to examine phenological anomalies-the camelback algorithm output is a valid indicator of the start of the season, even though it may indicate the end of snowmelt rather than the onset of photosynthetic activity. The latter event follows the former in natural environments. The remotely sensed peak of season, on average, occurs shortly after the flowering of Padus racemosa (Lam.), Malus palladiana (Juz.), and Sorbus sibirica (Hedl.), but long before the

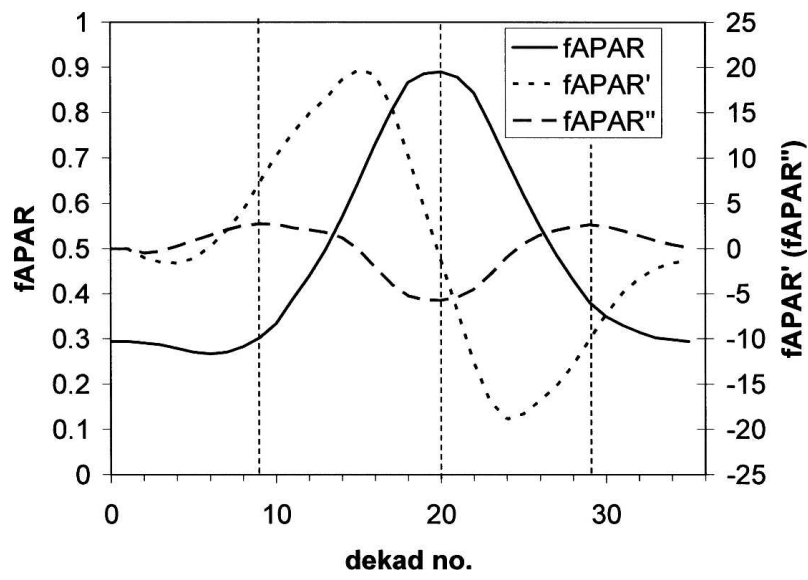

FIG. 2. Illustration of the phenological signal in the secondorder slope of the FASIR fAPAR time series data for one pixel location (pixel 74, line $253 ; 57.03^{\circ} \mathrm{N}, 95.01^{\circ} \mathrm{E}$ ) and $1 \mathrm{yr}(1995)$. (left $y$ axis) fAPAR; (right $y$ axis) first and second local derivatives of fAPAR. The typical "camelback" appearance of peak, trough, and second peak in the second-order derivative (dashed line) corresponds to the start, peak, and end of growing season indicators shown as vertical broken lines, which are determined based on the local maxima and minimum of the local second derivative.

onset of leaf shedding of Populus tremula (L.), Betula sp., and Larix sibirica (Ldb.). The remotely sensed end of season detects a stage between the first snowfall, close to Larix sibirica (Ldb.) shedding its needles, and shortly before the formation of a permanent snow cover. The indicators are thus consistent with fieldbased observations of vegetation activity.

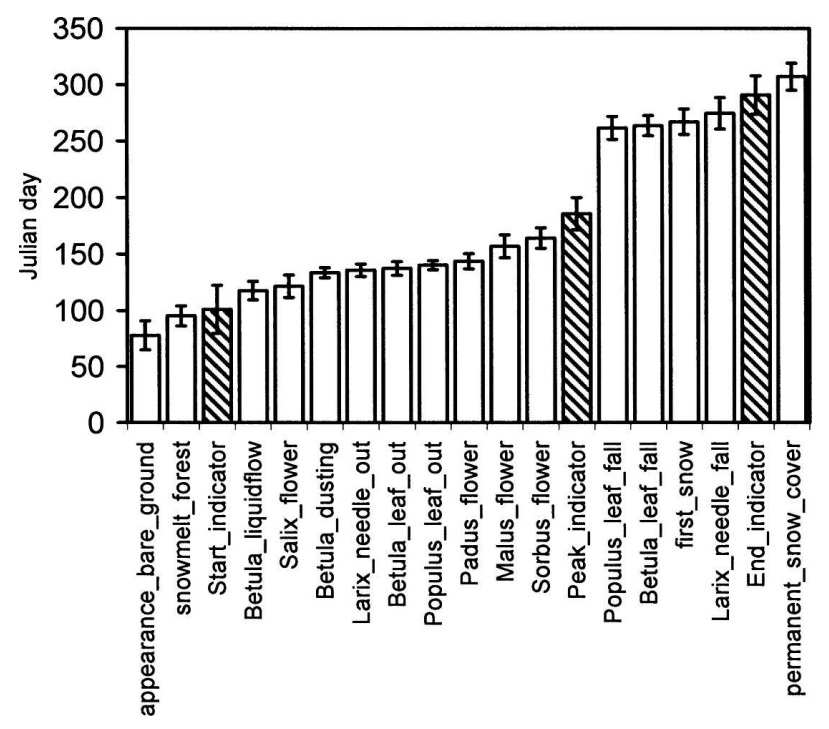

FIG. 3. Comparison of phenological indicators from field observations in Siberia at three sites over 5 years with the remotely sensed indicators "start," "peak," and "end" of growing season. Remotely sensed indicators are highlighted with a diagonal fill pattern. Shown is the mean Julian day of the events averaged over the years and sites. Bars show \pm one standard deviation. 
TABLE 1. Results of regression analysis of average start of season anomalies (in days) from 1982 to 1999 for each GLC2000 land-cover class.

\begin{tabular}{|c|c|c|c|c|c|}
\hline Land-cover class & Intercept & Slope & $r^{2}$ & Two-sided $p$ & Significance \\
\hline Barren tundra & 222.88 & -0.1120 & 0.04 & 0.4343 & NS \\
\hline Bogs and marshes & 503.39 & -0.2529 & 0.11 & 0.1691 & NS \\
\hline Broadleaf deciduous shrubs & 550.03 & -0.2763 & 0.13 & 0.1348 & NS \\
\hline Broadleaf/needle-leaf forest & 731.81 & -0.3677 & 0.10 & 0.1896 & NS \\
\hline Cropland-grassland complexes & 899.30 & -0.4518 & 0.18 & 0.0756 & $*$ \\
\hline Croplands & 692.01 & -0.3477 & 0.12 & 0.1496 & NS \\
\hline Deciduous broadleaf forest & 907.32 & -0.4558 & 0.25 & 0.0335 & $* *$ \\
\hline Deciduous needle-leaf forest & 25.25 & -0.0127 & 0.00 & 0.9471 & NS \\
\hline Evergreen needle-leaf forest & 650.83 & -0.3270 & 0.06 & 0.3334 & NS \\
\hline Forest-cropland complexes & 1234.17 & -0.6200 & 0.21 & 0.0524 & $*$ \\
\hline Forest-natural vegetation complexes & -216.09 & 0.1086 & 0.03 & 0.5102 & NS \\
\hline Humid grasslands & 699.32 & -0.3513 & 0.19 & 0.0685 & $*$ \\
\hline Mixed forest & 598.60 & -0.3007 & 0.06 & 0.3157 & NS \\
\hline Needle-leaf evergreen shrubs & 35.92 & -0.0180 & 0.00 & 0.9111 & NS \\
\hline Needle-leaf/broadleaf forest & 805.18 & -0.4045 & 0.08 & 0.2632 & NS \\
\hline Palsa bogs & 101.26 & -0.0509 & 0.01 & 0.7194 & NS \\
\hline Prostrate shrub tundra & 212.95 & -0.1070 & 0.05 & 0.3806 & NS \\
\hline Riparian vegetation & 524.48 & -0.2635 & 0.15 & 0.1056 & NS \\
\hline Saltmarsh & -135.23 & 0.0679 & 0.00 & 0.8657 & NS \\
\hline Sedge tundra & 171.24 & -0.0860 & 0.03 & 0.5002 & NS \\
\hline Shrub tundra & 135.66 & -0.0682 & 0.02 & 0.5833 & NS \\
\hline Steppe & -60.31 & 0.0303 & 0.00 & 0.8914 & NS \\
\hline Urban & 1474.92 & -0.7410 & 0.34 & 0.0104 & $* *$ \\
\hline
\end{tabular}

* Significance level: $p<0.1$.

** Significance level: $p<0.05$.

NS $=$ not significant $(p \geq 0.1)$.

\section{b. Land-cover analysis of phenological trends}

In this section the results from the linear regression analysis of average phenological anomalies for each of the 30 GLC2000 land-cover classes against time are described. Tables 1 to 4 show the statistical results for the start- (Table 1), peak- (Table 2), end- (Table 3), and length-of-season (Table 4) indicators. From 1982 to 1999 all but three land-cover classes showed an advance of the start-of-season indicator (negative slope over time), with urban areas $\left(0.74\right.$ day $\left.\mathrm{yr}^{-1}\right)$, deciduous broadleaf forest $\left(0.46\right.$ day $\left.\mathrm{yr}^{-1}\right)$, forest-cropland complexes (0.62 day $\left.\mathrm{yr}^{-1}\right)$, humid grasslands $\left(0.35\right.$ day $\left.\mathrm{yr}^{-1}\right)$, and cropland-grassland complexes $\left(0.45\right.$ day $\left.\mathrm{yr}^{-1}\right)$ being statistically significant $(p<0.1)$. Some examples of these trends are plotted in Fig. 4. All land-cover types except barren tundra, palsa bogs, broadleaf deciduous shrubs, and saltmarsh show a significant trend toward an earlier peak of the growing season (advance between 0.29 and 0.76 day $\mathrm{yr}^{-1} ; p<0.1$ ). A trend toward an earlier end of the season is detected for all classes except riparian vegetation, steppe, and broadleaf deciduous shrubs (advance between 0.27 and 0.57 day $\left.\mathrm{yr}^{-1} ; p<0.1\right)$. Palsa bogs, forest-natural vegetation complexes, prostrate shrub tundra, and sedge tundra were identified as showing a significant decrease in the length of season (shortening between 0.25 and 0.47 day $\left.\mathrm{yr}^{-1} ; p<0.1\right)$.

We repeated the analysis only for the years 19821991. The results are that between 1982 and 1991 all but two land-cover classes show a trend toward an earlier start of season, although only forest-cropland complexes (1.39 day $\left.\mathrm{yr}^{-1}\right)$ and urban areas (0.89 day $\left.\mathrm{yr}^{-1}\right)$ are statistically significant $(p<0.1)$. All of the classes show a trend toward an earlier peak of season, with about half of the classes indicating a statistically significant trend (sedge tundra, prostrate shrub tundra, barren tundra, bogs and marshes, croplands, croplandgrassland complexes, palsa bogs, shrub tundra, needleleaf evergreen shrubs, urban, riparian vegetation; advance between 0.71 and 1.18 day $\mathrm{yr}^{-1} ; p<0.1$ ). Steppe and croplands tended toward an earlier end of season $(p<0.1)$. The length of season between 1982 and 1991 showed a slight trend toward longer seasons (positive slopes) for most classes, but none of them statistically significant $(p>0.1)$. These findings for the shorter period from 1982 to 1991 would lead to different conclusions from the analysis of the full time series from 1982 to 1999, which indicates a slight shortening of the season.

In 1991 Mount Pinatubo erupted and emitted vast 
TABLE 2. Results of regression analysis of average peak of season anomalies (in days) from 1982 to 1999 for each GLC2000 land-cover class.

\begin{tabular}{|c|c|c|c|c|c|}
\hline Land-cover class & Intercept & Slope & $r^{2}$ & Two-sided $p$ & Significance \\
\hline Barren tundra & 366.56 & -0.1841 & 0.08 & 0.2638 & NS \\
\hline Bogs and marshes & 1078.78 & -0.5420 & 0.37 & 0.0068 & $* * *$ \\
\hline Broadleaf deciduous shrubs & 538.23 & -0.2704 & 0.08 & 0.2436 & NS \\
\hline Broadleaf/needle-leaf forest & 1509.77 & -0.7585 & 0.35 & 0.0093 & $* * *$ \\
\hline Cropland-grassland complexes & 1325.13 & -0.6657 & 0.49 & 0.0012 & $* * *$ \\
\hline Croplands & 1162.14 & -0.5838 & 0.46 & 0.0018 & $* * *$ \\
\hline Deciduous broadleaf forest & 1327.86 & -0.6671 & 0.42 & 0.0034 & $* * *$ \\
\hline Deciduous needle-leaf forest & 650.18 & -0.3266 & 0.19 & 0.0703 & $*$ \\
\hline Evergreen needle-leaf forest & 926.55 & -0.4655 & 0.22 & 0.0463 & $* *$ \\
\hline Forest-cropland complexes & 1490.26 & -0.7487 & 0.45 & 0.0021 & $* * *$ \\
\hline Forest-natural vegetation complexes & 985.69 & -0.4952 & 0.29 & 0.0198 & $* *$ \\
\hline Humid grasslands & 1046.62 & -0.5258 & 0.28 & 0.0236 & $* *$ \\
\hline Mixed forest & 1247.38 & -0.6267 & 0.32 & 0.0137 & ** \\
\hline Needle-leaf evergreen shrubs & 1003.17 & -0.5040 & 0.30 & 0.0175 & $* *$ \\
\hline Needle-leaf/broadleaf forest & 1301.48 & -0.6538 & 0.29 & 0.0199 & $* *$ \\
\hline Palsa bogs & 508.49 & -0.2555 & 0.09 & 0.2157 & NS \\
\hline Prostrate shrub tundra & 520.44 & -0.2615 & 0.14 & 0.1194 & NS \\
\hline Riparian vegetation & 724.76 & -0.3641 & 0.30 & 0.0180 & $* *$ \\
\hline Saltmarsh & 263.69 & -0.1325 & 0.01 & 0.6485 & NS \\
\hline Sedge tundra & 652.45 & -0.3278 & 0.16 & 0.1026 & NS \\
\hline Shrub tundra & 572.55 & -0.2876 & 0.17 & 0.0896 & $*$ \\
\hline Steppe & 555.81 & -0.2792 & 0.15 & 0.1127 & NS \\
\hline Urban & 1316.20 & -0.6612 & 0.44 & 0.0027 & $* * *$ \\
\hline
\end{tabular}

* Significance level: $p<0.1$.

** Significance level: $p<0.05$.

*** Significance level: $p<0.01$.

NS $=$ not significant $(p \geq 0.1)$.

amounts of gases and aerosols into the atmosphere. This raises the question whether the anomalous aerosol load after the eruption led to a degradation of the satellite signal that affects the interpretation of the landcover-specific results, or had an effect on temporal trends by causing temperature and precipitation anomalies in the years after the eruption. To evaluate whether Mount Pinatubo had a marked effect on the detected trends in the phenological anomalies, we calculated the regressions of anomaly indicators against time excluding the years 1991-94 from the analysis. The main changes to the detected temporal trends in the remote sensing indicators are that by excluding the post-Pinatubo years (i) in addition to the detected 5 classes with a temporal trend, the start of season anomaly indicator shows "bogs and marshes" and "riparian vegetation" also as significantly advancing (negative slope, $p<0.1$ ); (ii) out of the 16 classes showing an advance of the peak of season, this indicator no longer shows a significant trend for the class "shrub tundra" ( $p$ just over 0.1); (iii) the trends of the end-ofseason indicator are not affected (19 classes showing a significant advance); (iv) the length-of-season anomalies no longer show a significant trend for 2 out of 4 classes with a significant shortening of the season, namely "prostrate shrub tundra" and "sedge tundra" ( $p$ just over 0.1); (v) the sign of the slope of the trend is not affected for any of the land-cover classes showing a significant trend for any of the indicators with $p<0.1$. It can be concluded that Mount Pinatubo did not have a significant effect on the temporal trends.

\section{c. Modes of climatic variability and Siberian climatology}

Temperature anomalies on a $5^{\circ}$ grid were positively correlated with the annual Arctic Oscillation index (Fig. 5a, light green and blue colors) at longitudes between about $80^{\circ}$ and $140^{\circ} \mathrm{E}$. If the $\mathrm{AO}$ is in its positive phase, generally the annual temperatures in this region are higher than on average. This correlation is not significant in east Siberia beyond $140^{\circ} \mathrm{E}$, which has a more oceanic climate. In fact, the correlations are slightly negative in the east, but not statistically significant. The annual El Niño indices Niño-1+2, -3 , and -4 did not show significant correlations with annual temperature anomalies for the vast majority of grid boxes. Precipitation anomalies show negative correlations with the El Niño indices Niño-1+2 and -3 over large parts of the region, particularly east of $135^{\circ} \mathrm{E}$ (Fig. 5b, light red col- 
TABLE 3. Results of regression analysis of average end-of-season anomalies (in days) from 1982 to 1999 for each GLC2000 land-cover class.

\begin{tabular}{|c|c|c|c|c|c|}
\hline Land-cover class & Intercept & Slope & $r^{2}$ & Two-sided $p$ & Significance \\
\hline Barren tundra & 622.30 & -0.3126 & 0.28 & 0.0220 & $* *$ \\
\hline Bogs and marshes & 835.92 & -0.4200 & 0.48 & 0.0013 & $* * *$ \\
\hline Broadleaf deciduous shrubs & 74.43 & -0.0374 & 0.01 & 0.7562 & NS \\
\hline Broadleaf/needle-leaf forest & 1038.84 & -0.5219 & 0.33 & 0.0131 & ** \\
\hline Cropland-grassland complexes & 900.44 & -0.4524 & 0.32 & 0.0149 & $* *$ \\
\hline Croplands & 881.42 & -0.4428 & 0.44 & 0.0024 & $* * *$ \\
\hline Deciduous broadleaf forest & 544.05 & -0.2733 & 0.27 & 0.0266 & $* *$ \\
\hline Deciduous needle-leaf forest & 568.61 & -0.2857 & 0.28 & 0.0239 & $* *$ \\
\hline Evergreen needle-leaf forest & 1037.01 & -0.5210 & 0.30 & 0.0190 & $* *$ \\
\hline Forest-cropland complexes & 805.50 & -0.4047 & 0.23 & 0.0413 & $* *$ \\
\hline Forest-natural vegetation complexes & 841.17 & -0.4226 & 0.48 & 0.0015 & $* * *$ \\
\hline Humid grasslands & 626.86 & -0.3149 & 0.21 & 0.0534 & * \\
\hline Mixed forest & 884.34 & -0.4443 & 0.30 & 0.0191 & $* *$ \\
\hline Needle-leaf evergreen shrubs & 677.13 & -0.3402 & 0.37 & 0.0069 & $* * *$ \\
\hline Needle-leaf/broadleaf forest & 1130.58 & -0.5680 & 0.39 & 0.0057 & $* * *$ \\
\hline Palsa bogs & 848.40 & -0.4262 & 0.41 & 0.0043 & $* * *$ \\
\hline Prostrate shrub tundra & 702.30 & -0.3528 & 0.45 & 0.0023 & $* * *$ \\
\hline Riparian vegetation & 467.72 & -0.2350 & 0.12 & 0.1639 & NS \\
\hline Saltmarsh & 851.91 & -0.4280 & 0.13 & 0.1374 & NS \\
\hline Sedge tundra & 655.08 & -0.3291 & 0.42 & 0.0032 & $* * *$ \\
\hline Shrub tundra & 638.54 & -0.3208 & 0.43 & 0.0028 & $* * *$ \\
\hline Steppe & 140.08 & -0.0704 & 0.01 & 0.6272 & NS \\
\hline Urban & 765.35 & -0.3845 & 0.25 & 0.0319 & $* *$ \\
\hline
\end{tabular}

* Significance level: $p<0.1$.

** Significance level: $p<0.05$.

*** Significance level: two-sided $p<0.01$

NS $=$ not significant $(p \geq 0.1)$.

ors). The Arctic Oscillation is generally not correlated significantly with precipitation anomalies. The findings imply that that warm ENSO phases tend to coincide with lower precipitation over east Siberia on an annual time scale.

\section{d. Climatic controls of phenology anomalies}

Temperature anomalies were compared to the start-, peak-, end-, and length-of-season indicators from AVHRR fAPAR (Fig. 6). Temperature anomalies between February and April are negatively correlated with the start of season anomalies (Fig. 6a) because higher spring temperatures cause an earlier start of the growing season in the largely temperature-controlled ecosystems of Siberia. Temperature anomalies between May and July show a strongly negative correlation with the time of the peak of season (Fig. 6b). Anomalously warm summers coincide with an earlier peak of the growing season. Positive correlations are detected between temperature anomalies from August to October and the end-of-season anomalies (Fig. 6c), which means warmer autumn weather has the effect of delaying the end of the growing season. The length-of-season anomalies are correlated with a warm summer anomaly, averaged from April to September (Fig. 6d). These results confirm the consistency of the remotely sensed phenological anomaly indicators.

ENSO and AO indicators were compared to phenological anomalies. The length-of-season anomalies show significantly negative correlations between the El Niño indicators and length-of-season anomalies in eastern Siberia (e.g., Niño-3 east of $130^{\circ} \mathrm{E}$ in Fig. 7a). East Siberia had a shorter than average growing season in years with a positive El Niño index. Figures $7 b-d$ reveal that in years in which the Arctic Oscillation is in a more positive phase the vegetation season tends to start earlier and reach its peak earlier but also end earlier in most regions than in an average year.

It is evident that the Arctic Oscillation index is correlated with heat waves in the more continental parts of central Siberia between $80^{\circ}$ and $140^{\circ} \mathrm{E}$ (Fig. 5a), but El Niño years do not show a strong correlation with temperature anomalies in the region at an annual time scale. Generally, the Arctic Oscillation index is not, however, correlated significantly with precipitation anomalies of the same year. This result confirms the study by Frey and Smith (2003) in which the AO was linearly correlated with only $17 \%$ (winter), 13\% 
TABLE 4. Results of regression analysis of average length-of-season anomalies (in days) from 1982 to 1999 for each GLC2000 land-cover class.

\begin{tabular}{|c|c|c|c|c|c|}
\hline Land-cover class & Intercept & Slope & $r^{2}$ & Two-sided $p$ & Significance \\
\hline Barren tundra & 315.55 & -0.1584 & 0.04 & 0.4409 & NS \\
\hline Bogs and marshes & 98.03 & -0.0482 & 0.00 & 0.8374 & NS \\
\hline Broadleaf deciduous shrubs & -150.14 & 0.0757 & 0.01 & 0.7319 & NS \\
\hline Broadleaf/needle-leaf forest & 296.34 & -0.1489 & 0.02 & 0.6121 & NS \\
\hline Cropland-grassland complexes & 42.17 & -0.0208 & 0.00 & 0.9444 & NS \\
\hline Croplands & 171.84 & -0.0859 & 0.01 & 0.7750 & NS \\
\hline Deciduous broadleaf forest & -180.54 & 0.0908 & 0.01 & 0.6841 & NS \\
\hline Deciduous needle-leaf forest & 462.64 & -0.2324 & 0.06 & 0.3127 & NS \\
\hline Evergreen needle-leaf forest & -288.58 & 0.1454 & 0.01 & 0.7374 & NS \\
\hline Forest-cropland complexes & -211.83 & 0.1068 & 0.00 & 0.8028 & NS \\
\hline Forest-natural vegetation complexes & 922.86 & -0.4635 & 0.24 & 0.0367 & $* *$ \\
\hline Humid grasslands & 72.66 & -0.0364 & 0.00 & 0.8570 & NS \\
\hline Mixed forest & 284.95 & -0.1431 & 0.01 & 0.6883 & NS \\
\hline Needle-leaf evergreen shrubs & 692.88 & -0.3477 & 0.13 & 0.1400 & NS \\
\hline Needle-leaf/broadleaf forest & 114.93 & -0.0577 & 0.00 & 0.8874 & NS \\
\hline Palsa bogs & 933.96 & -0.4692 & 0.40 & 0.0045 & $* * *$ \\
\hline Prostrate shrub tundra & 500.61 & -0.2514 & 0.22 & 0.0510 & $*$ \\
\hline Riparian vegetation & 256.73 & -0.1290 & 0.02 & 0.5389 & NS \\
\hline Saltmarsh & 4.79 & -0.0026 & 0.00 & 0.9964 & NS \\
\hline Sedge tundra & 552.80 & -0.2776 & 0.18 & 0.0745 & $*$ \\
\hline Shrub tundra & 459.76 & -0.2308 & 0.14 & 0.1191 & NS \\
\hline Steppe & 70.58 & -0.0344 & 0.00 & 0.9128 & NS \\
\hline Urban & -650.87 & 0.3271 & 0.04 & 0.4036 & NS \\
\hline
\end{tabular}

* Significance level: $p<0.1$.

** Significance level: $p<0.05$.

*** Significance level: two-sided $p<0.01$.

$\mathrm{NS}=$ not significant $(p \geq 0.1)$

(spring), 12\% (summer), 1\% (autumn), and 26\% (annual) of precipitation trends in west Siberia. On the contrary, the El Niño indices show a correlation between El Niño years and droughts in the north and in the oceanic climate regions east of $135^{\circ} \mathrm{E}$ (Fig. 5b). Thus, a stratification of the region into continental climate (west of $140^{\circ} \mathrm{E}$ ) and oceanic climate (east of $140^{\circ} \mathrm{E}$ ) seems appropriate for understanding climatevegetation interactions in Siberia. The continental part of central Siberia is influenced more by the Arctic Oscillation, which is associated with temperature anomalies, while the oceanic part of east Siberia is influenced more by El Niño events in the Pacific, which coincide with dry years.

This regional climatology suggests two separate mechanisms of climatic control of biosphere anomalies in Siberia: (i) in central Siberia the Arctic Oscillation and the corresponding heat waves in the positive AO phase control the timing of the growing season and (ii) in east Siberia El Niño-induced droughts control the timing of the growing season.

\section{e. Climatic controls of the fire regime}

The two mechanisms that were proposed in the previous section are likely to have an impact on the re- gional fire regime. The validated remotely sensed burned forest area statistics of central Siberia from 1992 to 2003 by Balzter et al. (2005) showed that the Arctic Oscillation together with summer temperatures can explain $80 \%$ of the interannual variability of burned forest area. Observational evidence from the UNEP showed that Khabarovsk Kray in the far east of Siberia usually has a warm and humid summer, but in 1998 saw a severe drought (more information available online at http://www.grid.unep.ch/activities/global_change/ russia.php). The UNEP reports that fires started in May 1998 and lasted until October. The number of fires recorded was 1028 , and 18 enormous fires were registered, each one affecting between 200 and $350 \mathrm{~km}^{2}$. One million people were affected according to UNEP during weeks by smoke containing small particles and carbon monoxide. The UNEP states that the level of carbon monoxide reached between 3 and 13 times the maximum permissible concentration (MPC) over a period of weeks, with occasional levels reaching as high as 24 times MPC. The UNEP estimate is that the 1998 forest fires destroyed $20000 \mathrm{~km}^{2}$ of forest. An extreme El Niño year, 1998 saw huge forest fires in east Siberia but only moderate fire activity in central Siberia (Balzter et al. 2005). 

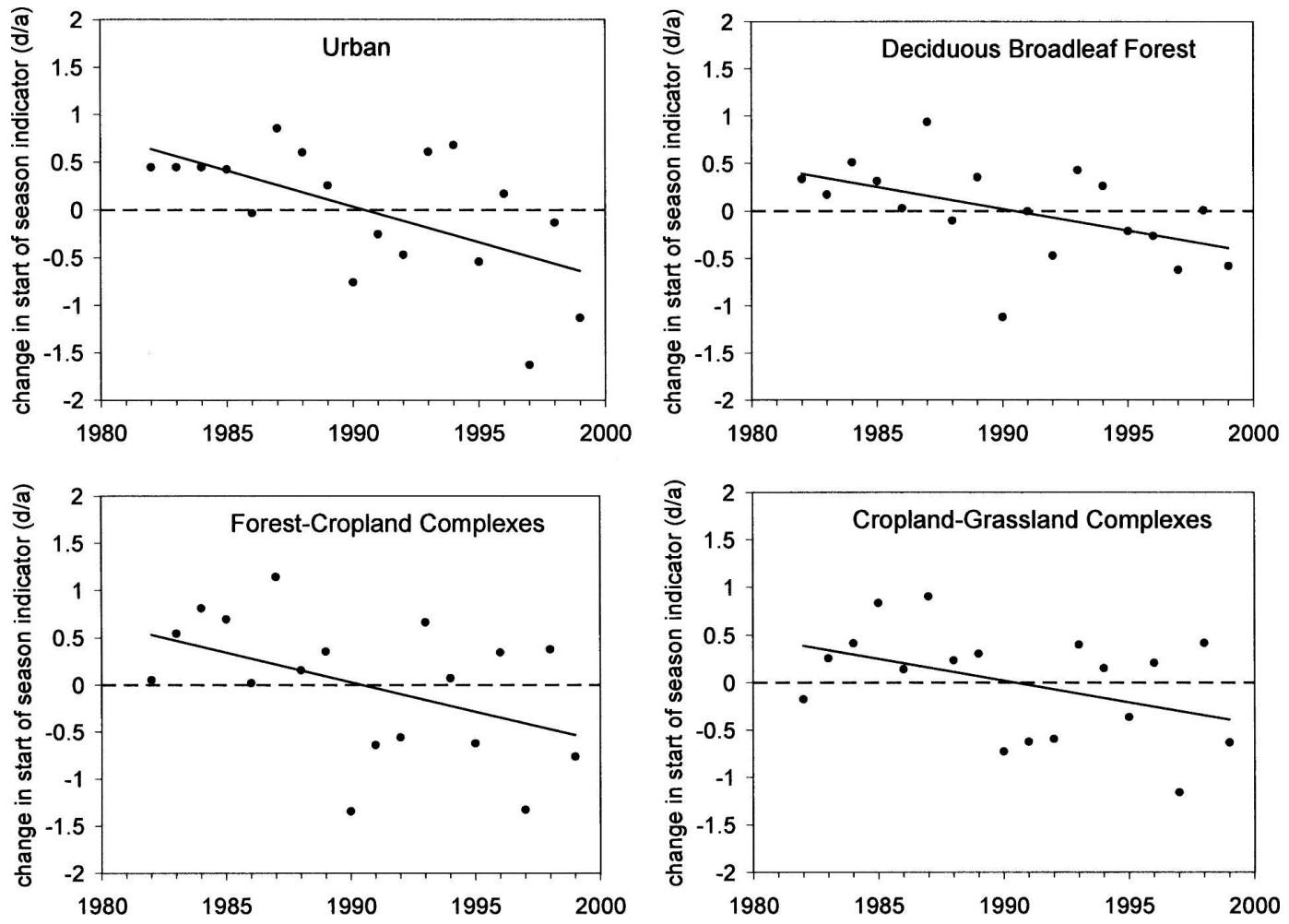

FIG. 4. Examples of temporal advances in the remotely sensed start of season indicator for four land-cover classes with fitted regression lines (all $p<0.1$ ).

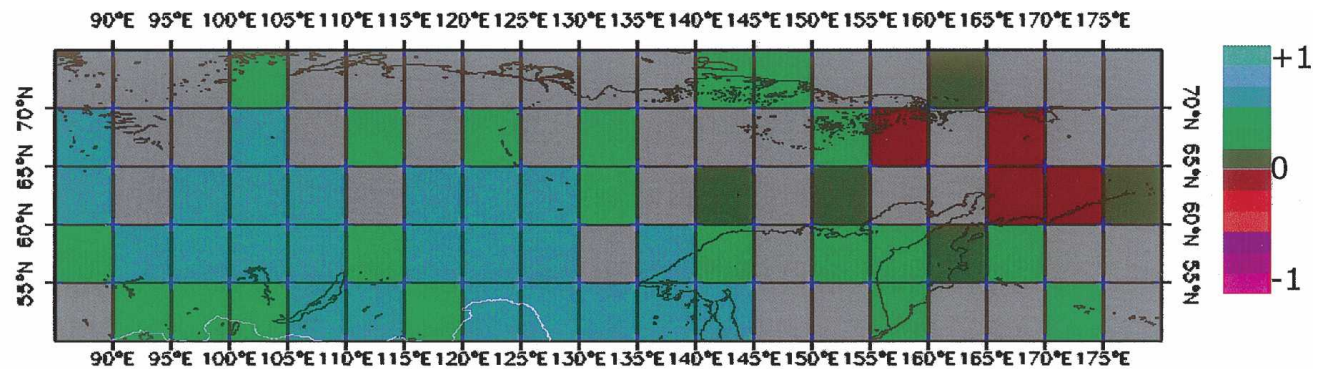

(a) Arctic Oscillation Index and temperature anomalies

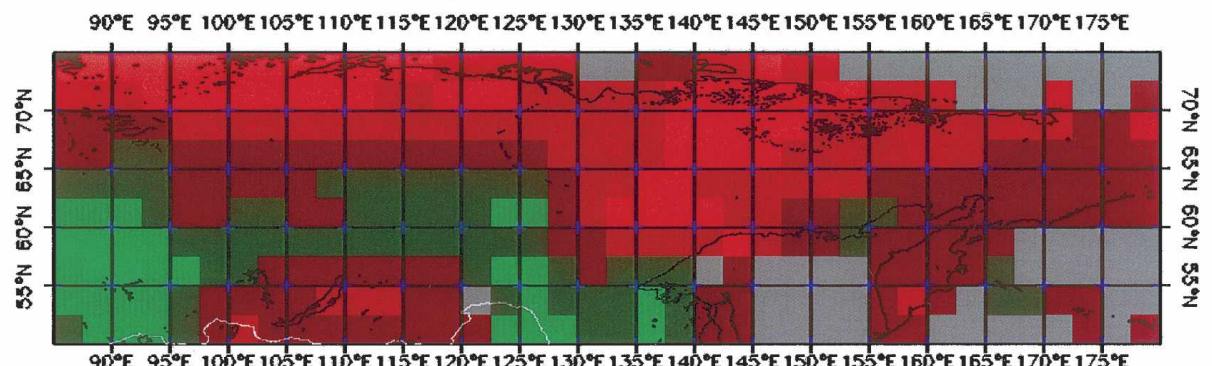

(b) NINO3 Index and precipitation anomalies

FIG. 5. (a) Correlation coefficient between the annual AO index and gridded temperature anomalies (CRUTEM2) on a $5^{\circ}$ grid. (b) Correlation coefficient between the annual Niño-3 index and gridded precipitation anomalies (GPCC) on a $2.5^{\circ}$ grid. Gray boxes: missing or zero values; black: coastlines; white: national boundaries; $r_{\text {crit }} \cong$ \pm 0.2778 ; gray zero values: missing values or values very close to zero. 


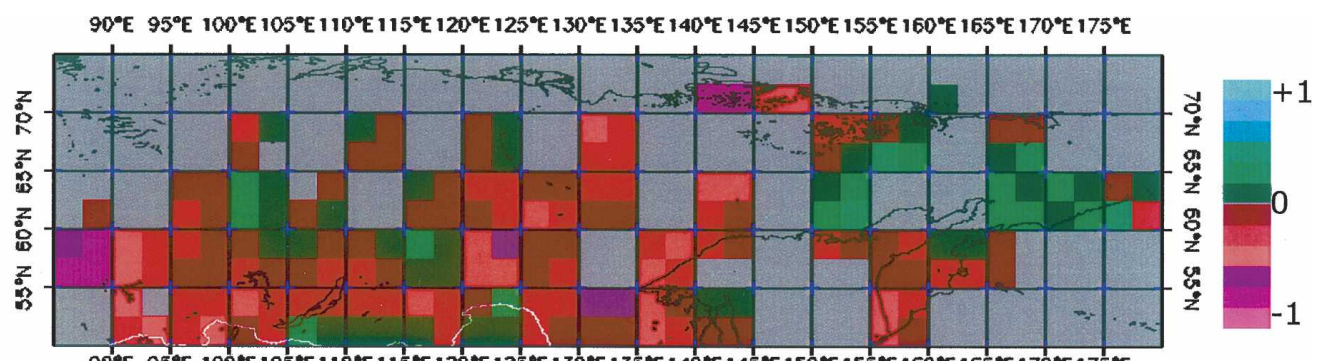

(a) Temperature anomalies months 2-4 / Start of season anomalies

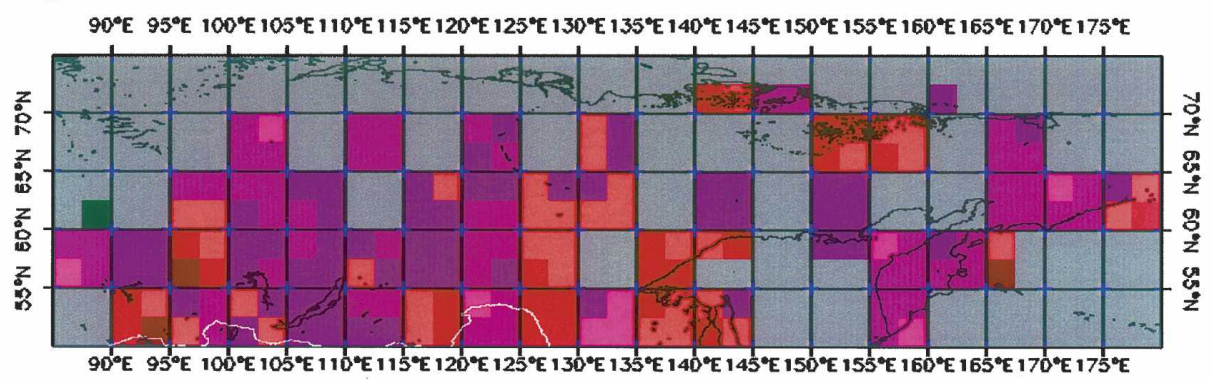

(b) Temperature anomalies months 5-7 / Peak of season anomalies

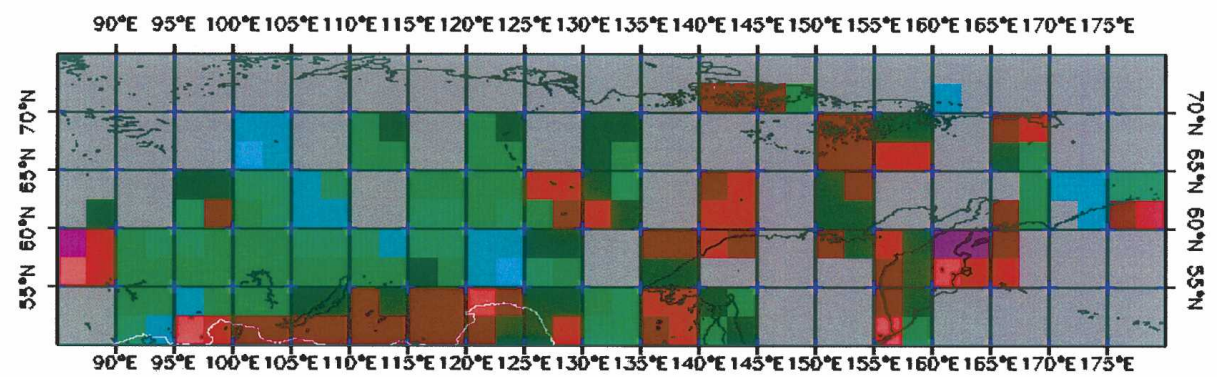

(c) Temperature anomalies months 8-10 / End of season anomalies

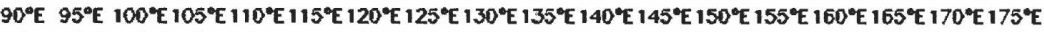

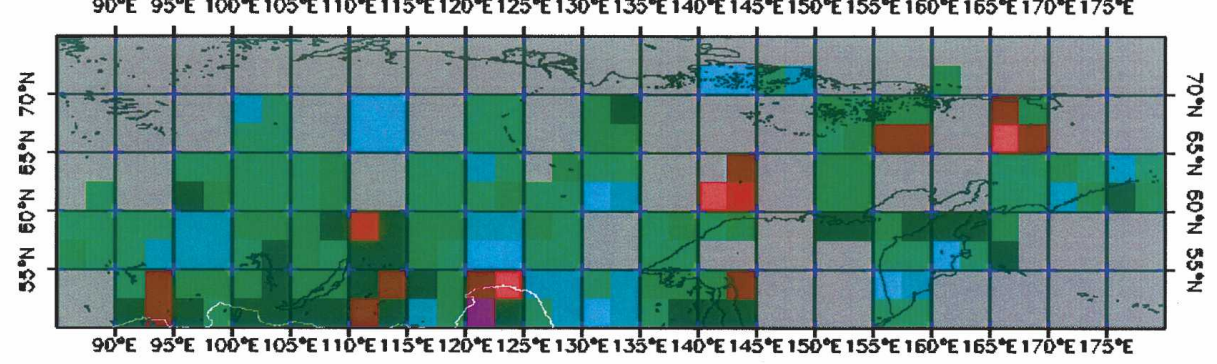

(d) Temperature anomalies months 4-9 / Length of season anomalies

FIG. 6. Correlation coefficient between annual temperature anomalies (CRUTEM2) and gridded vegetation phenological anomalies (from remote sensing) on a $5^{\circ}$ grid.

In 2002 a cluster of fires raged in east Siberia (Sukhinin et al. 2004), while the fire season in central Siberia was relatively calm. In the 2002 El Niño year the Arctic Oscillation index was close to zero. Annual burned forest area statistics derived from SPOT-VEGETATION from 2000 to 2004 (Bartalev et al. 2007) show that high fire activity over these five years in the Siberia macroregion coincided with a positive AO index (Fig. 8a), while the far eastern macroregion had higher fire activity in years with a positive El Niño index Niño-3 (Fig. $8 \mathrm{~b})$. Using forest fire statistics extracted from the dataset by Sukhinin et al. (2004), it is evident that the most extreme forest fire years in the central Siberia region (the Siberia-II study region) coincide with the Arctic Oscillation in its positive phase (Fig. 8c), but do not show an association with extreme El Niño years 


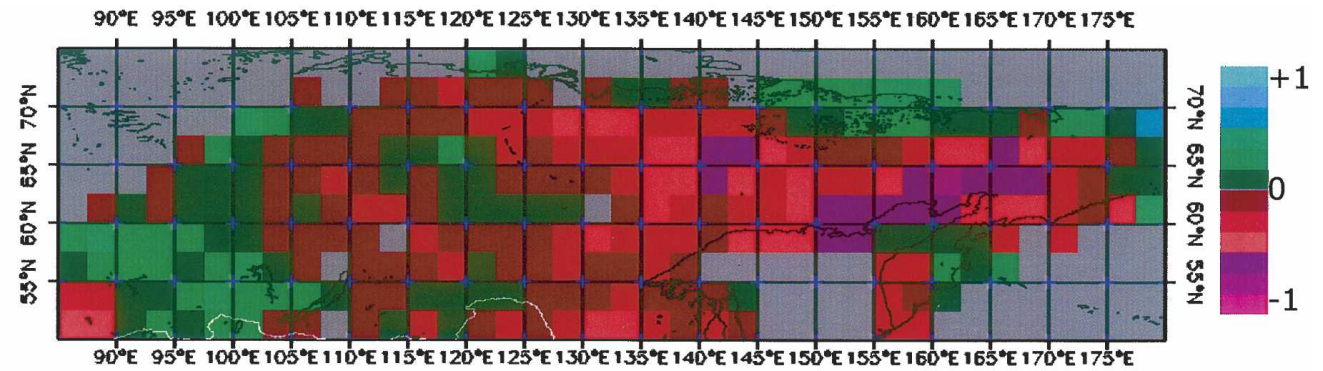

(a) NINO3 Index and length of season anomalies

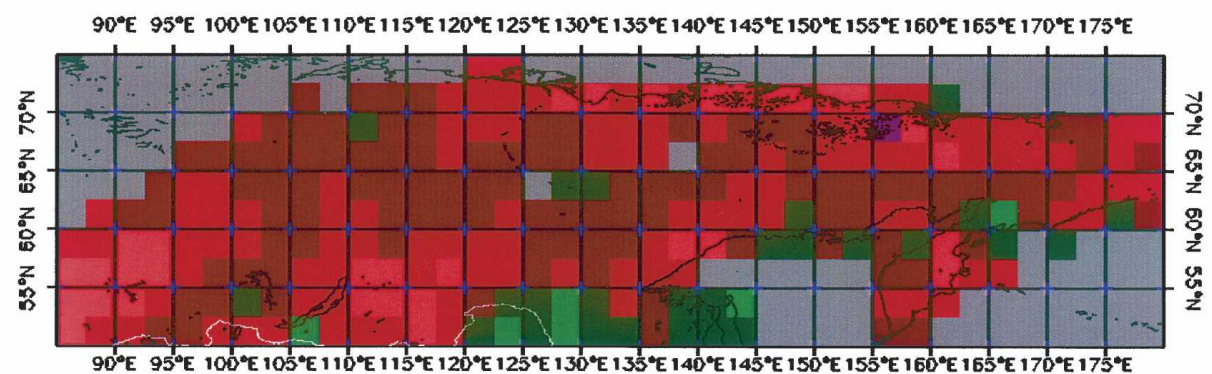

(b) Arctic Oscillation Index and start of season anomalies

$90^{\circ} \mathrm{E} 95^{\circ} \mathrm{E} 100^{\circ} \mathrm{E} 105^{\circ} \mathrm{E} 110^{\circ} \mathrm{E} 115^{\circ} \mathrm{E} 120^{\circ} \mathrm{E} 125^{\circ} \mathrm{E} 130^{\circ} \mathrm{E} 135^{\circ} \mathrm{E} 140^{\circ} \mathrm{E} 145^{\circ} \mathrm{E} 150^{\circ} \mathrm{E} 155^{\circ} \mathrm{E} 160^{\circ} \mathrm{E} 165^{\circ} \mathrm{E} 10^{\circ} \mathrm{E} 175^{\circ} \mathrm{E}$

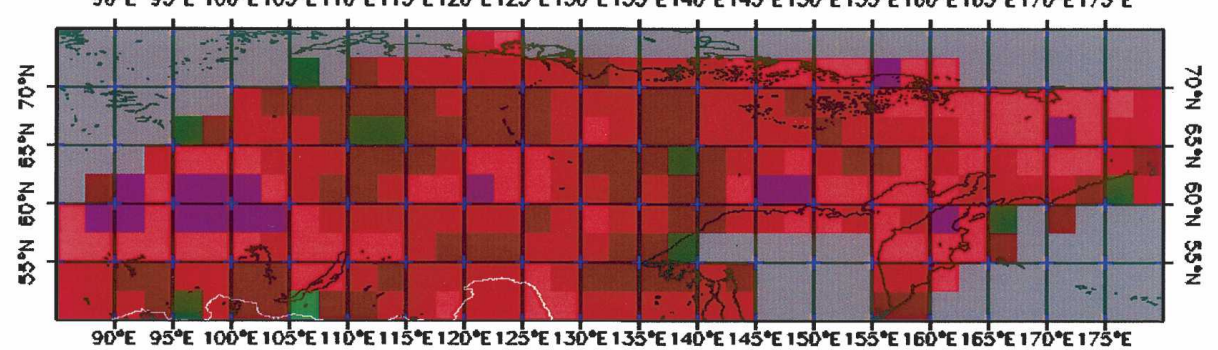

(c) Arctic Oscillation Index and peak of season anomalies

$90^{\circ} \mathrm{E} 95^{\circ} \mathrm{E} 100^{\circ} \mathrm{E} 105^{\circ} \mathrm{E} 11^{\circ} \mathrm{E} 115^{\circ} \mathrm{E} 120^{\circ} \mathrm{E} 125^{\circ} \mathrm{E} 130^{\circ} \mathrm{E} 135^{\circ} \mathrm{E} 140^{\circ} \mathrm{E} 145^{\circ} \mathrm{E} 150^{\circ} \mathrm{E} 155^{\circ} \mathrm{E} 160^{\circ} \mathrm{E} 165^{\circ} \mathrm{E} 170^{\circ} \mathrm{E} 175^{\circ} \mathrm{E}$

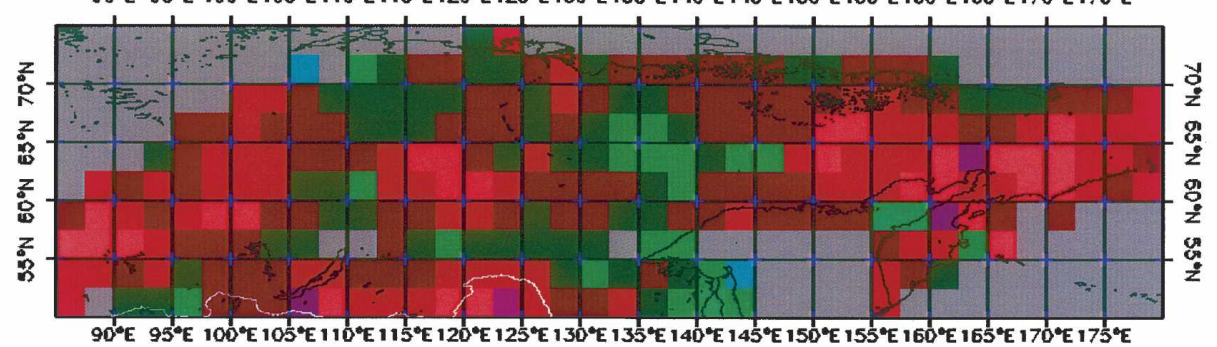

(d) Aretic Oscillation Index and end of season anomalies

FIG. 7. Correlations between the Niño-3 and AO index with vegetation phenological anomalies. Gray boxes: missing values or coefficient not significant (two-sided $p>0.1$ ). Black: coastlines, white: national boundaries.

(Fig. 8d). For the far eastern region the most extreme fire years also coincided with a positive Arctic Oscillation (Fig. 8c). The two most extreme fire years happened in years with a positive El Niño index (Fig. 8d).

The observational evidence from different forest fire data sources, derived using different remote sensing data and methods, partially supports the hypothesis that the central Siberian "Arctic Oscillation-tempera- ture mechanism" and the east Siberian "El Niñoprecipitation mechanism" have an impact on regional fire activity.

Since 1950 the Arctic Oscillation shows a statistically significant temporal trend toward the positive phase (Fig. 9), which is likely to lead to more frequent heat waves in central Siberia. El Niño indices also show a slight trend toward stronger El Niño years, albeit only 


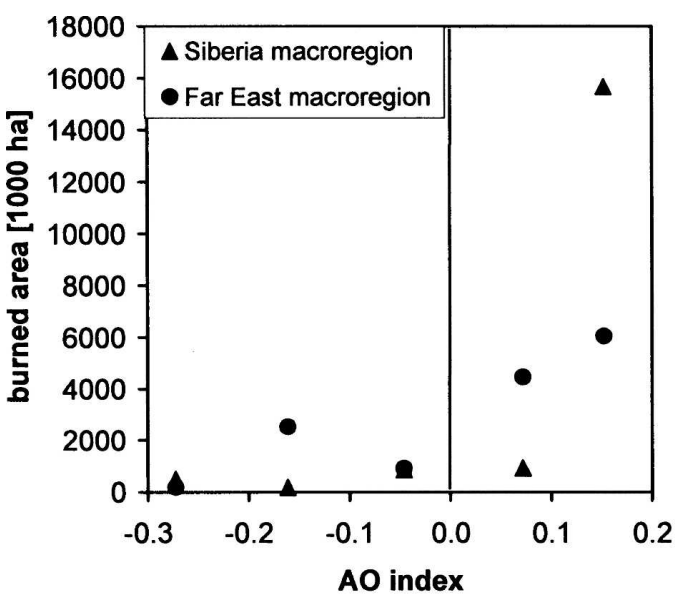

(a)

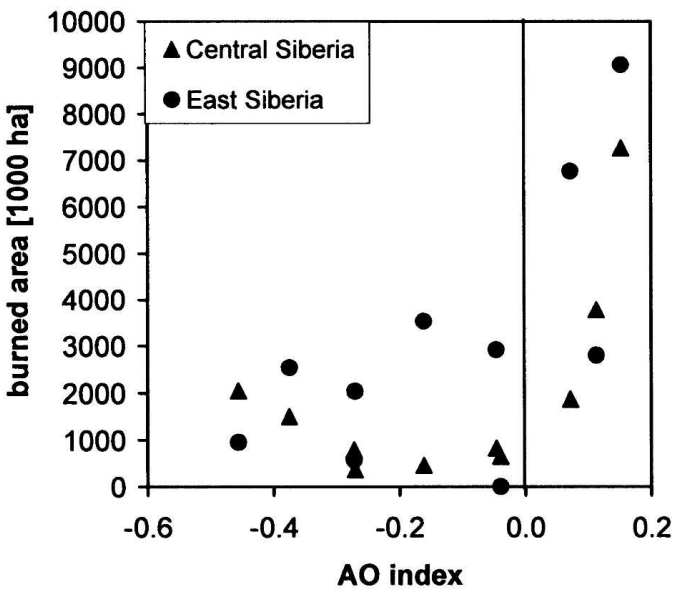

(c)

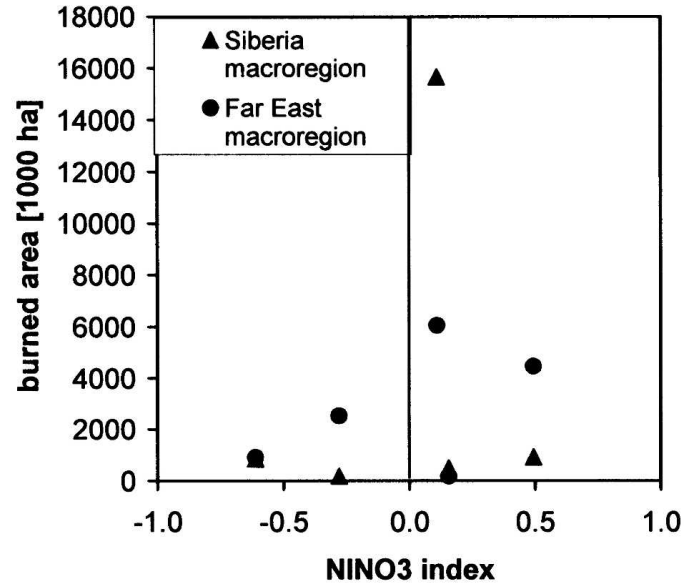

(b)

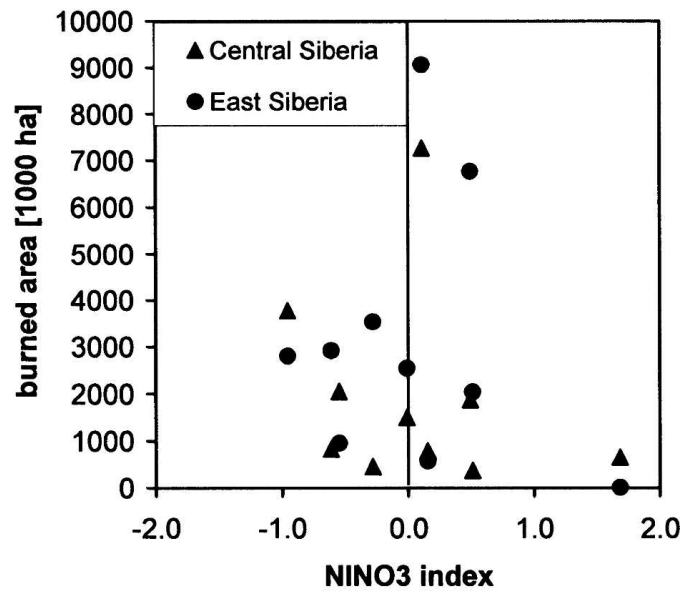

(d)

FIG. 8. Burned forest area statistics for more continental and more eastern regions of Siberia from remote sensing in relation to the AO index and the Niño-3 indicator. (a) Data from Bartalev et al. (2007) vs AO index; (b) data from Bartalev et al. (2007) vs Niño-3 anomalies; (c) data from Sukhinin et al. (2004) vs AO index; (d) data from Sukhinin et al. (2004) vs Niño-3 anomalies.

the Niño-4 sea surface temperature has a statistically significant increasing linear slope (Fig. 9). A possible consequence is an increased frequency of droughts in east Siberia with an accelerated fire regime.

\section{Discussion and conclusions}

The Arctic Oscillation is known to be associated with climatic variability over Eurasia. A correlation analysis of the northern Russian snow/ice season surface air temperature $(T)$ and winter (January-March) AO index from five stations showed that the winter $\mathrm{AO}$ accounts for $25 \%-50 \%$ of the winter and $15 \%-20 \%$ of the spring $T$ variance between 1935 and 1999 (Kryjov
2002). Gong et al. (2002) suggest that land surface forcings may play a considerable role in modulating the $\mathrm{AO}$ mode. Modeling evidence by Gong et al. showed that interannual variations in snow mass excite the AO pattern over the North Atlantic, produce correlated hemispheric AO features in the troposphere and stratosphere, and generate autumn sea level pressure anomalies over Siberia that evolve into the winter AO. These findings are consistent with the present study.

The Arctic Oscillation is correlated with temperature anomalies at longitudes between about $80^{\circ}$ and $140^{\circ} \mathrm{E}$, where a more continental climate prevails. If the $\mathrm{AO}$ is in its positive phase, generally the annual temperatures in this region are higher than on average. This correlation is not present in the region of east Siberia beyond 


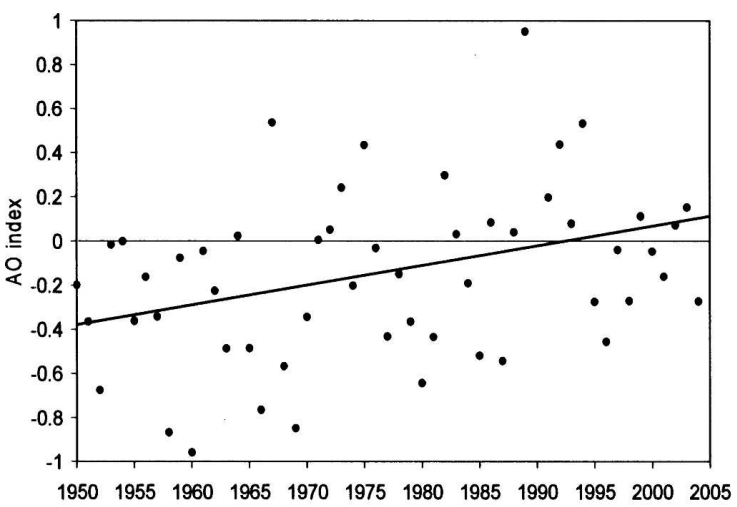

(a)

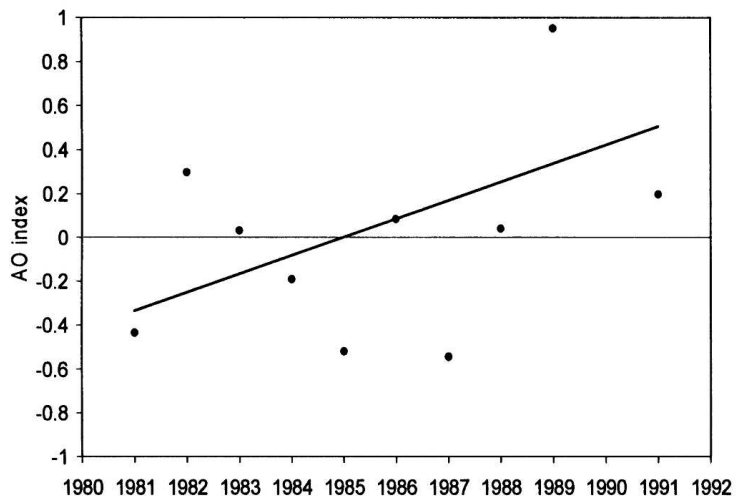

(c)

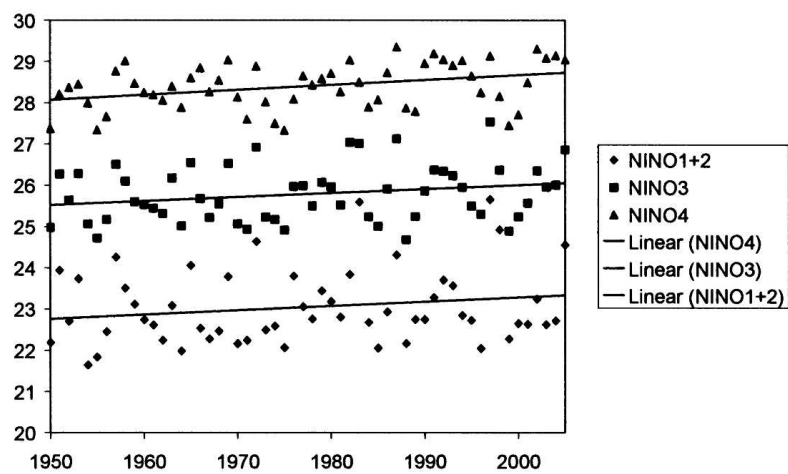

(b)

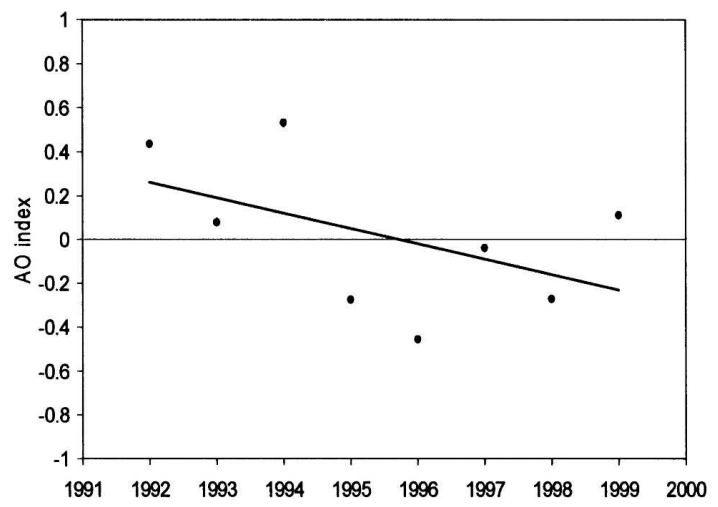

(d)

FIG. 9. Temporal trends of annual climatic oscillation indices: (a) AO index from 1950 to 2005 and trend line $(p<0.01)$; (b) El Niño indices Niño-1+2, -3 , and -4 (sea surface temperature, in ${ }^{\circ} \mathrm{C}$, in different regions of the Pacific) from 1950 to 2005 and trend lines (only Niño-4 shows a statistically significant increase: $p_{\mathrm{Niño}-1+2}>0.1 ; p_{\mathrm{Niño}-3}>0.1 ; p_{\mathrm{Niño}-4}<0.05$ ); (c) AO index from 1981 to 1991 and trend line $(p<0.1)$; (d) from 1992 to 1999 and trend line (not significant, $p>0.1$ ).

$140^{\circ} \mathrm{E}$, which has a more oceanic climate. El Niño years are associated with dry conditions in east Siberia.

The regional climatology of Siberia has implications for the fire regime. In the continental parts of central Siberia the Arctic Oscillation and corresponding hot years are thought to control the fire regime, while in east Siberia El Niño years and concurrent droughts are thought to play a major role. Evidence from burned forest area statistics of Siberia partially supports this hypothesis. Further research needs to be carried out to quantify the mechanisms that cause a coupling between regional and local weather conditions, snow cover dynamics, and the seasonal water cycle and the fire activity. A Siberian land surface experiment that unites surface-derived parameters with a land surface model that can be forced by weather data could be conducted to illuminate these mechanisms.

An analysis of the length of the growing season detected from remotely sensed fAPAR data between 1982 and 1991 showed a small increase of the length of season for the majority of land-cover classes (positive slope). However, an extension of the time series from 1982 to 1999 showed a slight tendency toward a shortening of the growing season for most land-cover classes. This change of direction coincided with a positive trend in the Arctic Oscillation between 1982 and 1991 ( $p<$ 0.1 ) switching to a nonsignificant negative trend (n.s., $p>0.1$ ) between 1992 and 1999 (Figs. 9c and 9d). This suggests that the lengthening of the growing season described in the literature is a nonlinear phenomenon resulting from a combination of biospheric responses to greenhouse-gas-induced climate change as well as climatic oscillations. We observed an association of $\mathrm{El}$ Niño with variations in the length of the growing season for parts of the region. In El Niño years eastern Siberia showed a shorter growing season. When the Arctic Oscillation was more in its positive phase, the vegetation season tended to start earlier and reach its peak earlier but also end earlier in most regions. The results are consistent with the findings by Delbart et al. (2006). 
For many land-cover classes we detected a shift toward an earlier peak and end of the growing season, which resulted on average in a slight shortening of the season between 1982 and 1999. Different land-cover types show different phenological responses to climate.

Acknowledgments. This work was supported by the European Union Framework 6 project GEOLAND (EC Proposal FP-6-502871), the Climate and Land Surface Systems Interaction Centre (CLASSIC), and the Natural Environment Research Council (United Kingdom). It was mainly carried out at the premises of the Joint Research Centre of the European Commission in Ispra, Italy, during a scientific visit by Heiko Balzter in 2005. Vegetation phenology data from field observations were kindly provided by Dr. Violetta Fedotova, the head scientist of the Phenology Research Group at the Institute of Botany, Komarov Russian Academy of Sciences, St. Petersburg, Russia. CRUTEM2 temperature anomaly data were provided by the Climate Research Unit, University of East Anglia, United Kingdom. We thank Jörg Kaduk (University of Leicester) for his comments on the manuscript.

\section{REFERENCES}

Abakumova, G. M., E. M. Feigelson, V. Russak, and V. V. Stadnik, 1996: Evaluation of long-term changes in radiation, cloudiness, and surface temperature on the territory of the former Soviet Union. J. Climate, 9, 1319-1327.

Asner, G. P., A. R. Townsend, and B. H. Braswell, 2000: Satellite observation of El Niño effects on Amazon forest phenology and productivity. Geophys. Res. Lett., 27, 981-984.

Badeck, F. W., A. Bondeau, K. Bottcher, D. Doktor, W. Lucht, J. Schaber, and S. Sitch, 2004: Responses of spring phenology to climate change. New Phytol., 162, 295-309.

Balzter, H., and Coauthors, 2005: Impact of the Arctic Oscillation pattern on interannual forest fire variability in Central Siberia. Geophys. Res. Lett., 32, L14709, doi:10.1029/2005GL022526.

Bartalev, S. A., A. S. Belward, D. V. Erchov, and A. S. Isaev, 2003: A new SPOT4 VEGETATION derived land cover map of Northern Eurasia. Int. J. Remote Sens., 24, 1977-1982.

, V. A. Egorov, E. A. Loupian, and I. A. Uvarov, 2007: Multiyear circumpolar assessment of the area burnt in boreal ecosystems using SPOT-VEGETATION. Int. J. Remote Sens., 28, 1397-1404.

Bogaert, J., L. Zhou, C. J. Tucker, R. B. Myneni, and R. Ceulemans, 2002: Evidence for a persistent and extensive greening trend in Eurasia inferred from satellite vegetation index data. J. Geophys. Res., 107, 4119, doi:10.1029/2001JD001075.

Buermann, W., B. Anderson, C. J. Tucker, R. E. Dickinson, W. Lucht, C. S. Potter, and R. B. Myneni, 2003: Interannual covariability in Northern Hemisphere air temperatures and greenness associated with El Niño-Southern Oscillation and the Arctic Oscillation. J. Geophys. Res., 108, 4396, doi:10.1029/2002JD002630.

Conard, S. G., A. I. Sukhinin, B. J. Stocks, D. R. Cahoon, E. P. Davidenko, and G. A. Ivanova, 2002: Determining effects of area burned and fire severity on carbon cycling and emissions in Siberia. Climatic Change, 55, 197-211.

Cox, P. M., R. A. Betts, C. D. Jones, S. A. Spall, and I. J. Totterdell, 2000: Acceleration of global warming due to carboncycle feedbacks in a coupled climate model. Nature, 408, 184 187.

de Beurs, K. M., and G. M. Henebry, 2005: A statistical framework for the analysis of long image time series. Int. J. Remote Sens., 26, 1551-1573.

Delbart, N., L. Kergoat, T. Le Toan, J. Lhermitte, and G. Picard, 2005: Determination of phenological dates in boreal regions using normalized difference water index. Remote Sens. Environ., 97, 26-38.

_, T. Le Toan, L. Kergoat, and V. Fedotova, 2006: Remote sensing of spring phenology in boreal regions: A free of snow-effect method using NOAA-AVHRR and SPOT-VGT data (1982-2004). Remote Sens. Environ., 101, 52-62.

Delworth, T., and S. Manabe, 1993: Climate variability and landsurface processes. Adv. Water Resour., 16, 3-20.

Frey, K. E., and L. C. Smith, 2003: Recent temperature and precipitation increases in West Siberia and their association with the Arctic Oscillation. Polar Res., 22, 287-300.

Gong, D.-Y., and C.-H. Ho, 2003: Detection of large-scale climate signals in spring vegetation index (normalized difference vegetation index) over the Northern Hemisphere. J. Geophys. Res., 108D, 4498, doi:10.1029/2002JD002300.

Gong, G., D. Entekhabi, and J. Cohen, 2002: A large-ensemble model study of the wintertime AO-NAO and the role of interannual snow perturbations. J. Climate, 15, 3488-3499.

Harding, R., P. Kuhry, T. R. Christensen, M. T. Sykes, R. Dankers, and S. van der Linden, 2002: Climate feedbacks at the tundra-taiga interface. Ambio, 12 (Special report), 47-55.

Houghton, R. A., 2000: Interannual variability in the global carbon cycle. J. Geophys. Res., 105, $20121-20130$.

Jaffe, D., I. Bertschi, L. Jaegle, P. Novelli, J. S. Reid, H. Tanimoto, R. Vingarzan, and D. L. Westphal, 2004: Long-range transport of Siberian biomass burning emissions and impact on surface ozone in western North America. Geophys. Res. Lett., 31, L16106, doi:10.1029/2004GL020093.

James, M. E., and S. N. V. Kalluri, 1994: The Pathfinder AVHRR land data set: An improved coarse resolution data set for terrestrial monitoring. Int. J. Remote Sens., 15, 3347-3363.

Jones, P. D., and A. Moberg, 2003: Hemispheric and large-scale surface air temperature variations: An extensive revision and an update to 2001. J. Climate, 16, 206-223.

Jupp, T. E., C. M. Taylor, H. Balzter, and C. T. George, 2006: A statistical model linking Siberian forest fire scars with early summer rainfall anomalies. Geophys. Res. Lett., 33, L14701, doi:10.1029/2006GL026679.

Kasischke, E. S., and L. P. Bruhwiler, 2003: Emissions of carbon dioxide, carbon monoxide, and methane from boreal forest fires in 1998. J. Geophys. Res., 108, 8146, doi:10.1029/ 2001JD000461.

— E. J. Hyer, P. C. Novelli, L. P. Bruhwiler, N. H. F. French, A. I. Sukhinin, J. H. Hewson, and B. J. Stocks, 2005: Influences of boreal fire emissions on Northern Hemisphere atmospheric carbon and carbon monoxide. Global Biogeochem. Cycles, 19, GB1012, doi:10.1029/2004GB002300.

Kharuk, V. I., M. L. Dvinskaya, and K. J. Ranson, 2005: The spatiotemporal pattern of fires in northern Taiga larch forests of central Siberia. Russ. J. Ecol., 36, 302-311.

Koster, R. D., M. J. Suarez, and M. Heiser, 2000: Variance and 
predictability of precipitation at seasonal-to-interannual timescales. J. Hydrometeor., 1, 26-46.

Kryjov, V. N., 2002: The influence of the winter Arctic oscillation on the northern Russia spring temperature. Int. J. Climatol., 22, 779-785.

Langenfelds, R. L., R. J. Francey, B. C. Pak, L. P. Steele, J. Lloyd, C. M. Trudinger, and C. E. Allison, 2002: Interannual growth rate variations of atmospheric $\mathrm{CO}_{2}$ and its delta $\mathrm{C}-13, \mathrm{H}-2$, $\mathrm{CH}_{4}$, and $\mathrm{CO}$ between 1992 and 1999 linked to biomass burning. Global Biogeochem. Cycles, 3, 21-1-21-22.

Los, S. O., G. J. Collatz, L. Bounoua, P. J. Sellers, and C. J. Tucker, 2001: Global interannual variations in sea surface temperature, land surface temperature and land surface vegetation air temperature and precipitation. J. Climate, 14, 1535-1549.

Lucht, W., and Coauthors, 2002: Climatic control of the highlatitude vegetation greening trend and Pinatubo effect. Science, 296, 1687-1689.

Mattis, I., A. Ansmann, U. Wandinger, and D. Müller, 2003: Unexpectedly high aerosol load in the free troposphere over central Europe in spring/summer 2003. Geophys. Res. Lett., 30, 2178, doi:10.1029/2003GL018442.

Moulin, S., L. Kergoat, N. Viovy, and G. Dedieu, 1997: Globalscale assessment of vegetation phenology using NOAA/ AVHRR satellite measurements. J. Climate, 10, 1154-1170.

Müller, D., I. Mattis, U. Wandinger, A. Ansmann, D. Althausen, and A. Stohl, 2005: Raman lidar observations of aged Siberian and Canadian forest fire smoke in the free troposphere over Germany in 2003: Microphysical particle characterization. J. Geophys. Res., 110, D17201, doi:10.1029/ 2004JD005756

Myneni, R. B., C. D. Keeling, C. J. Tucker, G. Asrar, and R. R. Nemani, 1997: Increased plant growth in the northern high latitudes from 1981 to 1991. Nature, 386, 698-702.

Nemani, R. R., C. D. Keeling, H. Hashimoto, W. M. Jolly, S. C. Piper, C. J. Tucker, R. B. Myneni, and S. W. Running, 2003: Climate-driven increases in global terrestrial net primary production from 1982 to 1999. Science, 300, 1560-1563.

Overland, J. E., M. Wang, and N. A. Bond, 2002: Recent temperature changes in the western Arctic during spring. J. Climate, 15, 1702-1716.
Roy, J., B. Saugier, and H. A. Mooney, 2001: Global Terrestrial Productivity: Past, Present and Future. Academic Press, 572 pp.

Rudolf, B., H. Hauschild, W. Rueth, and U. Schneider, 1994: Terrestrial precipitation analysis: Operational method and required density of point measurements. Global Precipitations and Climate Change, M. Desbois and F. Desalmond, Eds., NATO ASI Series I, Vol. 26, Springer-Verlag, 173-186.

-, T. Fuchs, U. Schneider, and A. Meyer-Christoffer, 2003: Introduction of the Global Precipitation Climatology Centre (GPCC). Deutscher Wetterdienst, 16 pp. [Available online at http://www.dwd.de/en/FundE/Klima/KLIS/int/GPCC/ Reports_Publications/QR/GPCC_Introduction.pdf.]

Samsonov, Y. N., and Coauthors, 2005: Particulate emissions from fires in central Siberian Scots pine forests. Can. J. Forest Res., 35, 2207-2217.

Slayback, D. A., J. E. Pinzon, S. O. Los, and C. J. Tucker, 2003: Northern Hemisphere photosynthetic trends 1982-99. Global Change Biol., 9, 1-15.

Spichtinger, N., and Coauthors, 2004: Boreal forest fires in 1997 and 1998: A seasonal comparison using transport model simulations and measurement data. Atmos. Chem. Phys., 4, 1857-1868.

Stockli, R., and P. L. Vidale, 2004: European plant phenology and climate as seen in a 20-year AVHRR land-surface parameter dataset. Int. J. Remote Sens., 25, 3303-3330.

Sukhinin, A. I., and Coauthors, 2004: AVHRR-based mapping of fires in Russia: New products for fire management and carbon cycle studies. Remote Sens. Environ., 93, 546-564.

van der Werf, G. R., J. T. Randerson, G. J. Collatz, L. Giglio, P. S. Kasibhatla, A. F. Arellano, S. C. Olsen, and E. S. Kasischke, 2004: Continental-scale partitioning of fire emissions during the 1997 to 2001 El Niño/La Niña period. Science, 303, 73-76.

Vicente-Serrano, S. M., N. Delbart, T. Le Toan, and M. Grippa 2006: El Niño-Southern Oscillation influences on the interannual variability of leaf appearance dates in central Siberia. Geophys. Res. Lett., 33, L03707, doi:10.1029/2005GL025000.

Wild, M., and Coauthors, 2005: From dimming to brightening: Decadal changes in solar radiation at Earth's surface. Science, 308, 847-850. 